\title{
A Peculiar Cone-like Specimen from the Shizukuishi Basin, Iwate Prefecture, Northeast Japan
}

\author{
By \\ Motohiko TADA* \\ 岩手県雲石盆地の特殊な円錐状構造をもつた化石標本について \\ 多田元彦
}

岩手県零石盈地汇発達する新第三系の層位学的 ならびに堆積学的研究を行なつておる途上, 岩手 ポゾラン採石現場付近に発達する中新世上部の桝 沢層上部から円錐形構造をもつたコンクリーショ ン様のものを大手することができた。これは当時 の堆積環境を知るうえに重要な手がかりになるも のではなかるうかと考えて研究し，次のような結 果を得えのでこれを報告する。

この円錐形構造をもつたものは湖成堆積物と考 えられている柝沢層から発見されたが，これとよ く形体が類似したクリンドリクヌスは海成堆積物 から発見されている。

この円錐形構造をもつたものはさや状の外壁と 内部とから流つて就り，さや状の外壁は褐鉄鉱よ りなり，環状のふくらみをもつている以外は何も 認められないし, 内部は硅藻質細粒凝灰岩からで きており，七プタ状の下にくぼんだラミナが発達 し，褐鉄鈗のシミがついている。
これにやや類似したものにディプロクラテリオ ンやリゾコラリウムがあるが, 内部構造, 外壁の 形態, 軸の方向, 大きさ等にそれぞれ相異がみと められ，同一視することはできない。今までの文 献にはこれと同一と考えられるものは著者の知る かぎりではみあたらないが，不完全な標本なので 命名を控えておく。

生成環境は植物化石や淡水硅藻化石から湖成層 であり，現在と同じ高度であつたなら今より寒冷 であつたと考えられる。その生成の水深度につい ては決定する資料を持たないが，桝沢層の上部か ら発見されている。

成因については，非常に困難では㐫るが，㤓沢 層の上部に発見される植物化石や亚炭䂶展物をも たらした樹木の幹・枝の内部が朽ちて, その後に 堆積物が充填され，その外壁となる樹皮があとで 褐鉄鈗によつて置換されたものと考えられるが, まだ確定的ではない。

\section{Introduction and Acknowledgements}

A peculiar cone-shaped specimen showing remote resemblance with Kulindrichnus (Doughty, 1965) in shape but not in size, material or in details. The present specimen is from a lacustrine deposit whereas Kulindrichnus is described from a marine deposit. The peculiar specimen was given to the writer by an employee of the Iwate Pozzolan Company near Shizukuishi Town.

The specimen was found in the Masuzawa Formation (Murai, 1962) exposed in a

* Faculty of Engineering, Iwate University. 
quarry about $1.5 \mathrm{~km}$ northeast of Oshuku along the Oshuku River in the Shizukuishi Basin, Iwate-gun, Iwate Prefecture. It was found in the middle part of a concretion-like oval. shaped, soft, fine grained tuff in the upper part of the Masuzawa Formation. The oval shaped concretionary structure measured about one or a little more meters in longer diameter and about 50 to 60 centimeters in shorter one, being oriented with the longer diameter in vertical position. Owing to the quarrying, the original concretionary structure is no longer observable

The specimen now under consideration is more or less of narrow cone-shape and was found in the soft tuff sediment of the concretion-like oval ball in vertical position with the larger diameter facing upwards and the smaller one directed downwards. The original. length probably did not exceed that of the concretionary structure in which it was enclosed.

Since such kind of specimen has not been described from the Cenozoic or older rocks. of the Japanese Islands, the writer feels that its description and illustrations may contribute: to our knowledge on the concretionary and various shaped structures occurring in marine: or lacustrine deposits.

At this place the writer expresses his cordial thanks to Professor Kotora Hatai and Assistant Professor Nobu Kitamura of the Institute of Geology and Paleontology, Tohoku. University, for their kind instructions in the field and laboratory. Deep appreciation is expressed to Professor Sadamasa Murai of the Faculty of Technology, Iwate University, for his sincere encouragement and suggestions with regard to the writer's research. Thanks, are due to Mr. Hidezo Kanki and Mr. Gensei Kamemaru of the Iwate Pozzolan Company for the permission to make geological studies of their quarry and also for donating the: present specimen to the writer for study.

\section{Stratigraphic Position of the Peculiar Specimen}

As already stated above the peculiar shaped specimen was found in the Masuzawa. Formation, a unit which occupies the stratigraphic position shown in Table 1 (Murai, 1962).

The Masuzawa Formation is distributed throughout the Shizukuishi Basin and is composed of, according to Murai (1962), "tuff and tuffaceous shale frequently with pumiceous. tuff and conglomerate intercalated. The tuff and sandy tuff are often with banded stratification or with intercalated thin layers of shaly tuff or tuffaceous shale." The formation. has yielded fossils of brackish and freshwater shells (Anodonta sp., cfr. A. lauta Martens), freshwater diatoms (Epithemia zebra var., E. turgida var., E. sorex var., Melosira granulata, Eunotia zebrium, E. zebrium var., Orephora Martyi var., Rhoicosphenia curvata), and abundant fossil plants which are called the Gosho Flora by Murai (1962). The fossils, especially the plants point to that the geological age of the formation is late Miccene.

\section{Description of the Specimen}

A single cylindrical cone-like specimen measuring $110 \times 130 \mathrm{~mm}$ in diameter at preserved upper or wider part, $84 \times 95 \mathrm{~mm}$ in diameter at preserved lower part, about $165 \mathrm{~mm}$ in height as preserved (would be much longer if complete), and with external wall or sheath. attaining $4-7 \mathrm{~mm}$ in thickness. The specimen is broken at both upper and lower parts, thus its original length is unknown. Its shape as noticed from the measurements, is not perfectly round in cross-section, but was probably a long more or less conical cylinder narrowing towards the lower end, which may have been bluntly rounded. The external surface of the specimen has broadly rounded convex annulations, separated from one another 
Table 1. Stratigraphic Sequence of the Formations in the Western, Eastern, Central and Southern Parts of the Shizukuishi Basin, Iwate Prefecture (After Murai, 1962).

\begin{tabular}{|c|c|c|c|c|c|}
\hline & & Western Part & \multirow{2}{*}{\multicolumn{2}{|c|}{$\begin{array}{l}\text { Southern and } \\
\text { Central Parts } \\
\begin{array}{c}\text { Takamatsuzawa } \\
\text { Formation }\end{array}\end{array}$}} & Eastern Part \\
\hline \multirow{9}{*}{ 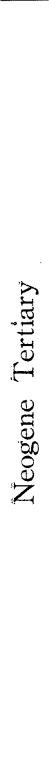 } & 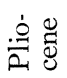 & & & & \\
\hline & \multirow{8}{*}{ 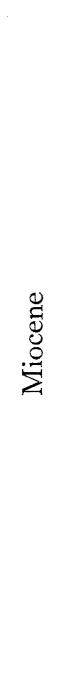 } & $\begin{array}{l}\text { Hashiba } \\
\text { Formation }\end{array}$ & $\begin{array}{l}\text { Hashiba } \\
\text { Formation }\end{array}$ & \multirow{3}{*}{$\begin{array}{l}\text { Aonokimori } \\
\text { Formation }\end{array}$} & \\
\hline & & $\begin{array}{l}\text { Masuzawa } \\
\text { Formation }\end{array}$ & $\begin{array}{l}\text { Masuzawa } \\
\text { Formation }\end{array}$ & & $\begin{array}{l}\text { Masuzawa } \\
\text { Formation }\end{array}$ \\
\hline & & & $\begin{array}{l}\text { Yabitsu } \\
\text { Formation }\end{array}$ & & $\begin{array}{l}\text { Yabitsu } \\
\quad \text { Formation }\end{array}$ \\
\hline & & $\begin{array}{l}\text { Sakamotogawa } \\
\text { Formation }\end{array}$ & \multirow{2}{*}{\multicolumn{2}{|c|}{ Osuke Formation }} & \multirow{2}{*}{ Osuke Formation } \\
\hline & & $\begin{array}{r}\text { Koshitomaezawa } \\
\text { Formation }\end{array}$ & & & \\
\hline & & $\begin{array}{l}\text { Ryukawa } \\
\text { Formation }\end{array}$ & \multicolumn{2}{|c|}{ Ryukawa Formation } & Shimosaruta Formation \\
\hline & & $\begin{array}{l}\text { Kunimitoge } \\
\text { Formation }\end{array}$ & & & \\
\hline & & $\begin{array}{l}\text { Rentaki } \\
\text { Formation }\end{array}$ & & & Ioka Formation \\
\hline \multicolumn{2}{|c|}{$\begin{array}{l}\text { Pre- } \\
\text { Tertiary }\end{array}$} & $\begin{array}{l}\text { Metamorphosed } \\
\text { Paleozoics and } \\
\text { Granitic Rocks }\end{array}$ & & & $\begin{array}{l}\text { Metamorphosed } \\
\text { Paleozoics }\end{array}$ \\
\hline
\end{tabular}

by narrow but well rounded shallow concave valleys. Both annulations and valleys are not uniform in their development. The largest and most expanded annulation occurs near the preserved uppermost part of the cylinder. No external scaulpture except for the annulations and valleys are recognized. The external wall or sheath is firm, $4-7 \mathrm{~mm}$ in thickness and its outer part or external surfuce is dark brown as if limonitic, stained irregularly at places, its inner surface is of fine grained tuff and stained darker as mottles or banded. The external surface of the specimen brownish yellow in color and stained here and there as mot-

\section{Explanation of Plate}

All figures reduced to one half natural size. Photo: K. Kumagai

Figs. 1, 2. External views of the specimen to show the annulations, stained portions, concave layers, limonitic sheath, and general shape.

Figs. 3, 4. Top (fig. 3) and bottom (fig. 4) views of Figs. 1 and 2 respectively. Fig. 3 shows the concave surface of the uppermost layer and fig. 4 the plugged nature of the sediments. The sheath of limonitic material is well displayed.

Figs. 5, 6. Longitudinal views to show the concave shaped layers extending throughout the specimen, the development of limonitic material of the sheath, and gradual downward narrowing sides. 


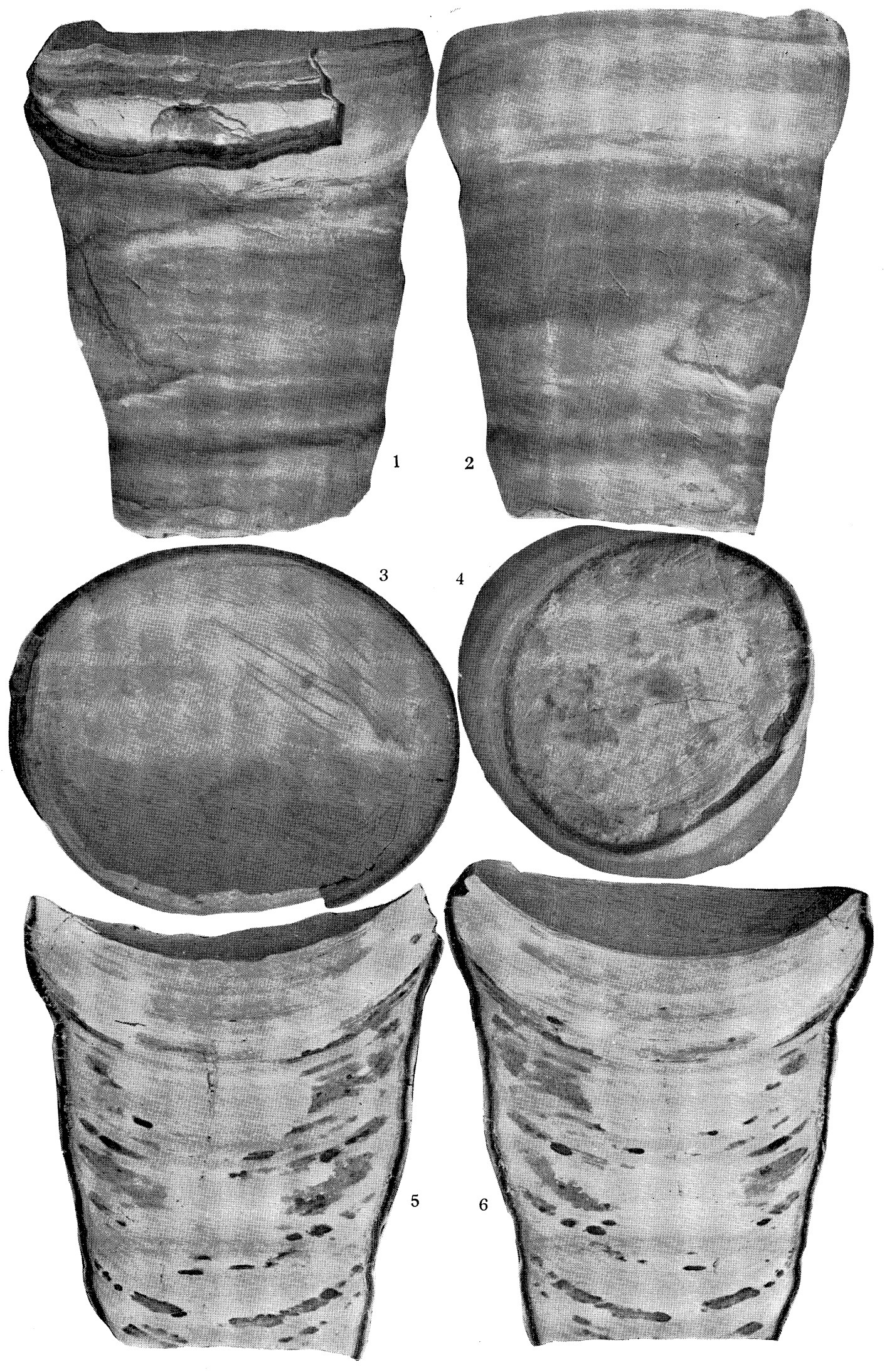


tles with some banding. The material filling the cone-like specimen consists of diatomaceous (Melosira islandica O. Müller, M. distans (Ehr.) Kütz., Stephanodiscus astrea var. minutula (Kütz.) Gnow., Cyclostella sp., Fragilaria sp., Melosira sp. : these were identified by Mr. Itaru Koizumi, graduate student in Institute of Geology and Paleontology, Tohoku University, to whom the writer takes this opportunity to express his deep thanks), fine grained tuff. The diatomaceous fine grained tuff deposited in the cylinder is of concave form like the septa of orthocones. Each concave septa-like layer is about $7-10 \mathrm{~mm}$ in thickness and consists of many laminae, from very thin paper thickness to rather thick lamina of about $1 \mathrm{~mm}$.

In longitudinal section, it was found that the concave septa-like layers extended from top to bottom of the preserved part of the cylindrical structure, with no change in the degree of curvature of the concavity, development of the layers and their laminae. However, the upper nearly $33 \mathrm{~mm}$ thick part of the cylinder, or the rather widely expanded part is filled with fine grained tuff of whitish yellow color whereas the part below is colored more deeply yellowish and stained bands are developed. The limnitic part of the sheath extends from top to bottom of the cone-like cylinder as now preserved.

\section{Remarks on the Specimen}

It was already mentioned above that the present specimen shows remote resemblance to Kulindrichnus. The general shape of Kulindrichnus langi Hallam, 1960, described and figured by Doughty (1965, p. 146, fig. 1) from the Lower Lias "Limestone beds of the Bucklandi Zone extending along the Frondingham Ironstone escarpment from Messingham, 3 miles south of Scunthorpe, to Whitton, on the Humber, in the northwest of the country" shows a more or less remote resemblance to the present specimen. The orientation of the apex or narrower part directed downward and the cylindrical or conical shape of the Lias specimens are quite the same in the Japanese specimen, except for the size and mode of occurrence. Kulindrichnus is said to be normally of "indurated small shells and shell fragments and a sheath of phosphatic rock is sometimes found around the specimens". In the present specimen a limonitic sheath forms the external wall and no shells or fragments of any kind are found adhered.

From the just described features it is evident that the present specimen cannot be referred to the genus Kulindrichnus, or to any previously described and formally named one, so far as the writer is aware.

Although it may be advisable to propose a generic name for the peculiar specimen described in this article for the sake of convenience in its use in stratigraphy, correlation and problems related with paleoenvironment, the writer refrains at present from such procedure because the specimen is not a complete one and more should be studied.

Diplocraterion parallelum (Torell) figured by Hallam (1963, p. 562, fig. 4, a and b) shows some resemblance to the present one in having plugged tubes, but differs in the tubes not being U-shaped, of small size or parallel straight walls as in that genus. However, the convex structure of the sediments filling the tube seem to be analogous even though Diplocraterion is of marine origin and the present one of lacustrine environment.

Rhizocorallium jenense Zenker figured by Hallam (1963, p. 562, fig. 4c) is stated to be of much larger size than Diplocraterion parallelum and with curved axis which is oriented more or less parallel to the bedding whereas the latter named one is vertical in position.

Literature on concretions and concretionary structures are abundant, but so far as the 
writer has been able to find, there are none with which the present one can be identified.

For the reasons mentioned above it is difficult to explain the process by which the present specimen developed. However, from the fossil flora (Murai, 1962) and the freshwater diatom fiora identified by Koizumi (from sediments scraped off the present specimen) as well as those listed by Murai (1962), it seems evident that the lacustrine sediments were deposited under a climatic condition cooler than at the present day at the same altitude and latitude, because the original lake may have occupied a higher altitude and or the temperature may have been lower. There is no evidence by which the depth of deposition of the sediments in which the specimen was found can be determined, except that it was found in the upper part of the Masuzawa Formation. On the other hand there is no evidence to show that the depth of the lake water was great.

It is assumed that the specimen was made on a lake bottom influenced with cool water, at a moderate depth, not subjected to agitation or bottom currents (ripple-marks, crossbedding and other water make structures have not been observed), but under tranquil conditions. Whether the production of the specimen was associated with or related with the sedimentary structure produced by subaqueous slumping remains to be settled. However, even it was related therewith the explanation of the limonitic sheath is difficult to interpret.

Although plant leaves and lignitic materials have been found from upper part of the Masuzawa Formation, whether the endoderm of some water plant or the external covering of some submerged land pland root, stem or trunk could have been responsible for the making of the limonitic sheath, and the decayed and hollow inner part later filled from above by depositing sediments is another problem to be considered. At present it is considered that the limonitic sheath of the specimen was originally part of a plant, later decayed and transformed into limonite, and the inner parts were also decayed to form a hollow tube which was latter filled by sediments deposited from above.

\section{References}

Doughty, P. S. (1965): Trace Fossils of the Liassic Rocks of Northwest Lincolnshire. Mercian Geologist, Vol. 1, No. 2, p. 143-152, 1 table, pl. 6, 7.

Hallam, A. (1960): Kulindrichnus langi, A New Trace Fossil from the Lias. Paleont., Vol. 3, p. 64-68, pl. 15, text-fig. 1.

Katto, J. (1965): A Note on Some Concretions from the Muroto Formation (Eocene) of Kochi Prefecture, Shikoku, Japan. Kochi Univ., Res. Rep., Vol. 14, Nat. Sci., 1, No. 2, p. 7-28, 1 table, pl. 1-3 (with bibliography).

Murai, S. (1962): Geology and Paleobotany of the Shizukuishi Basin, Iwate Prefecture, Japan. (Part 1.). Irwate Univ., Rep. Tech., Vol. 15, No. 1, p. 131-193, 10 tables, 3 figs. 